\title{
COMPARATIVE ANALYSIS OF FATTY ACID PROFILE AND CHOLESTROL CONTENT IN TABLE EGGS FROM DIFFERENT GENOTYPE HENS
}

\author{
Z. Pavlovski ${ }^{1}$ Z. Śkrbić $^{1}$, M. Lukićc ${ }^{1}$, S. Lilić ${ }^{2}$, V. Krnjaja ${ }^{1}$, N. Stanišićc ${ }^{1}$ \\ V. Petričević ${ }^{1}$ \\ ${ }^{1}$ Institute for Animal Husbandry, Autoput 16, Belgrade-Zemun, Republic of Serbia \\ ${ }^{2}$ Institute of Meat Hygiene and Technology, Kaćanskog 13, Beograd, Republic of Serbia \\ Corresponding author: zlaticapav@yahoo.com \\ Original scientific paper
}

Abstract: Alternative (non-conventional) poultry housing systems are introduced into production, on the one hand for the benefit of poultry welfare and, on the other hand because of the quality of eggs, i.e. the association/correlation between quality of life of hens and quality of product is established. Data obtained in the comparative analysis for proximate composition, fatty acid profile and cholesterol content of whole egg of genotype (Hy line and Naked N) housed in different systems (cage and free range) are presented in this study. Eggs from Naked Neck hens reared in free range system had statistically significantly higher content of dry matter, fat, protein and ash compared to genotype Hy line housed in both systems. Eggs obtained from genotype Hy line hens reared in free range system, in comparison to cage system, had higher content of dry matter, fat and ash, although the differences were not statistically significant, whereas the difference in the protein/albumen content in Hy line hens housed in cages compared to free range was statistically significant. Significantly lower content of n-6 fatty acids was established in eggs from Naked Neck hens (13.32) compared to eggs obtained from Hy-line hens housed on free range (17.46) and Hy-line hens housed in cage system (18.02). Content of toxic elements $(\mathrm{Cd}<0.001 \mathrm{mg} / \mathrm{kg} ; \mathrm{Pb}<$ $0.05 \mathrm{mg} / \mathrm{kg}$; As $<0.01 \mathrm{mg} / \mathrm{kg} ; \mathrm{Hg}<0.005 \mathrm{mg} / \mathrm{kg}$ ) in all three groups of eggs was in compliance with standards stipulated in the Article 9a, Annex 5, Rulebook on maximum residue limits for plant protective compounds in food and feed for which maximum reside limits are established.

Key words: housing system, genotype, table egg, chemical content, fatty acid profile 


\section{Introduction}

Quality of table eggs is a property of dynamic character and depends on numerous factors. Of biological factors, the greatest impact on the quality of table eggs have genotype, gender and age, and of zoo-technical factors major factors are housing system, nutrition, health condition of hens, with special emphasis on table quality of eggs (Pavlovski et al., 2010). Alternative (non-conventional) poultry housing systems are introduced into production for the benefit of poultry welfare, on one hand, and on the other because of the quality of eggs, i.e. the association is established between the quality of life of hens and quality of product (Pavlovski et al., 2001; Appleby, 2001).

Only few authors in Serbia has investigated rearing of hen and egg quality in non-conventional housing systems (Pavlovski et al., 2002; Đukić-Stojčić et al., 2009; Perić et al. 2007; Pavlovski et al., 2009; Pavlovski et al., 2010; Senčić et al., 2006). Even greater need for new alternative systems appeared following the adoption of the Rulebook on animal welfare in Serbia, in February 2010, banning the housing of layer hens in batter cages starting from 2012.

In production of eggs in the extensive system, as one of the alternative systems, domestic native hens, Naked neck hen, domestic populations of Rhode island, new Hampshire, Amrok and Plymouth rock breeds are used instead of hybrids, as well as crosses obtained by crossing of these breeds, i.e. hens of coloured plumage.

Data obtained in the comparative analysis for proximate composition, fatty acid profile and cholesterol content in the whole egg content in genotypes -Hy line and Naked Neck hens housed in different housing system (cage and free range) are presented in this paper.

\section{Materials and Methods}

Hens were reared in the Experimental Centre of the Institute for Animal husbandry, Belgrade-Zemun, Hy - line genotype in cages and on free range, and Naked Neck hens in free range system. Eggs used in the examination of the chemical composition were collected every 7 days, 6 eggs per group in 6 weekly repetitions.

Analysis of fatty acids profile, cholesterol and heavy metal contents were performed at the Institute of Hygiene and Meat Technology (Belgrade, Serbia) and analysis of chemical content of eggs at the Institute for animal husbandry (Belgrade, Serbia).

Proximate composition of eggs was determined by the following methods:

- Dry matter content - by drying at the temperature of $103^{\circ} \mathrm{C}$;

- Ash content (mineral substances) - by combustion at $525^{\circ} \mathrm{C}$; 
- Protein content- according to Kjeldahl;

- Fat content- according to Soxhlet extraction method.

Methods are described in the AOAC (1990).

Total lipids for fatty acids determination were extracted from whole eggs by accelerated solvent extraction (ASE 200, Dionex, Sunnyvale, CA). Homogenate of sample, mixed with diatomaceous earth, was extracted with a mixture of nhexane and iso-propanol (60:40 v/v) in $33 \mathrm{ml}$ extraction cell at $100^{\circ} \mathrm{C}$ and nitrogen pressure of 10.3 MPa (Spirić et al., 2009). The extracts were collected and the solvent was removed under stream of nitrogen in Dionex Solvent Evaporator 500, at $50^{\circ} \mathrm{C}$ until dryness. Fat extract was further used for fatty acids and cholesterol determination in whole eggs.

Fatty acid methyl esters (FAMEs) were prepared by transesterification by using trimethylsulfonium hydroxide, according to SRPS EN ISO 5509:2007 procedure. The GC instrument Shimadzu 2010 (Kyoto, Japan), used for FAMEs determination, was equipped with a split/splitless injector, fused silica cianopropyl HP-88 column (length $100 \mathrm{~m}$, i.d. $0.25 \mathrm{~mm}$, film thickness $0.20 \mu \mathrm{m}$ ) and flame ionization detector (FID). The column temperature was programmed. Injector temperature was set at $250^{\circ} \mathrm{C}$ and detector temperature at $280^{\circ} \mathrm{C}$. The carrier gas was nitrogen, at a flow rate of $1.33 \mathrm{ml} / \mathrm{min}$. Injector split ratio was set at 1:50.

The total share of saturated fatty acids (SFA) consisted of the weight percentages sum of myristic (14:0), pentadecanoic (15:0), palmitic (16:0), margaric (17:0) and stearic (18:0) acids. The total share of monounsaturated fatty acids (MUFA) was calculated by summing the weight percentages of palmitoleic (16:1c), oleic (18:1c9) and gadoleic (20:1). Additionally, the total percentage of polyunsaturated fatty acids (PUFA) included linoleic (18:2n6), $\gamma$-linolenic (18:3n6), $\alpha$-linolenic (18:3n3), eicosadienoic (20:2), dihomo- $\gamma$-linolenic (20:3n6), docosapentaenoic (22:5n-3) and docosahexaenoic (22:6n-3) acid.

The sum of all n-6 fatty acids (18:2n-6, 18:3n-6 and 20:3n-6) was divided by the sum of all n-3 fatty acids (18:3n-3, 22:5n-3, and 22:6n-3) to calculate the n6/n-3 ratio.

Cholesterol determination in whole eggs (from lipid extract obtained by ASE) was performed by using HPLC/PDA system (Waters 2695 Separation module/Waters photodiode array detector, USA) on a Phenomenex Luna C18 (2) reverse/phase column, $150 \mathrm{~mm} \times 3.0 \mathrm{~mm}, 5 \mu \mathrm{m}$ particle size, with $\mathrm{C} 18$ analytical guard column, $4.0 \times 2.0 \mathrm{~mm}$, according to Maraschiello et al. (1996). The injected volume was $10 \mu \mathrm{L}$. The mobile phase was isopropanol-acetonitrile $(20: 80, \mathrm{v} / \mathrm{v})$ at a flow rate of $1.2 \mathrm{~mL} / \mathrm{min}$, isocraticaly. Detection was performed at $210 \mathrm{~nm}$. Total analysis time lasted $10 \mathrm{~min}$. Quantification of cholesterol was done by external standardization. Empower Pro software was used to control the HPLC system as well as for data acquisition and data processing.

For determination of toxic elements (cadmium, $\mathrm{Cd}$; lead, $\mathrm{Pb}$; arsenic, $\mathrm{As}$; and mercury, $\mathrm{Hg})$ sample $(0.75 \mathrm{~g})$ was weighed and digested with $8 \mathrm{ml}$ of $\mathrm{HNO}_{3}$ 
and $1.5 \mathrm{ml} \mathrm{H}_{2} \mathrm{O}_{2}$ in a microwave digestion system. Determination of toxic elements in all samples was carried out by using a Varian SpectrAA 220 atomic apsorbtion spectrofotometer. Determination of $\mathrm{Pb}$ and $\mathrm{Cd}$ was performed by using a Varian GTA 110 model graphite furnace. As was determend with Hydride generation technique and $\mathrm{Hg}$ with Cold vapour technique by using Varian VGA 77 model on the same spectrofotometer.

Data on proximate composition of eggs were statistically analyzed by method of variance analysis and Tukey test (Stat.Soft,Inc. STATISTICA, version $6)$.

\section{Results and Discussion}

Proximate composition of eggs obtained from Hy-line genotype reared in cages and free range system and of autochthonous Naked Neck hen reared in free range system is presented in Table 1.

Table 1. Chemical composition of examined eggs $\left({\left.\mathrm{g} 100 \mathrm{~g}^{-1}\right)}^{-1}\right.$

\begin{tabular}{|c|c|c|c|c|c|c|c|c|}
\hline $\begin{array}{c}\text { Genotype } \\
\text { housing } \\
\text { system }\end{array}$ & \multicolumn{2}{|c|}{ Dry matter } & \multicolumn{2}{c|}{ Fat } & \multicolumn{2}{c|}{ Protein } & \multicolumn{2}{c|}{ Ash } \\
\cline { 2 - 10 } & Average & $\mathrm{Sd}$ & Average & $\mathrm{Sd}$ & Average & $\mathrm{Sd}$ & Average & $\mathrm{Sd}$ \\
\hline $\begin{array}{c}\text { Hy line }- \\
\text { free range }\end{array}$ & $23.04^{\mathrm{a}}$ & 2.13 & $9.43^{\mathrm{a}}$ & 2.04 & $11.93^{\mathrm{a}}$ & 0.66 & $0.90^{\mathrm{ab}}$ & 0.07 \\
\hline $\begin{array}{c}\text { Hy line }- \\
\text { cage }\end{array}$ & $22.94^{\mathrm{a}}$ & 1.01 & $8.76^{\mathrm{a}}$ & 0.88 & $12.34^{\mathrm{b}}$ & 0.40 & $0.88^{\mathrm{a}}$ & 0.05 \\
\hline $\begin{array}{c}\text { Naked } \\
\text { Neck- free } \\
\text { range }\end{array}$ & $25.59^{\mathrm{b}}$ & 1.17 & & 0.90 & & 0.63 & & 0.06 \\
\hline$p$ & \multicolumn{2}{|c|}{$p<0.01$} & \multicolumn{2}{|c|}{$p<0.01$} & \multicolumn{3}{|c|}{$p<0.01$} & \multicolumn{2}{c|}{$p<0.01$} \\
\hline
\end{tabular}

Based on presented data it can be concluded that eggs of naked neck hens reared in free range system had highly significantly greater content of dry matter, protein and ash compared to genotype Hy line reared in both systems. Eggs of genotype Hy line reared in free range system compared to cage system had higher content of dry matter, fat and ash, although differences were not statistically significant, whereas the difference in the protein content between Hy line hens housed in cages compared to those on free range was statistically significant. 
Table 2. Fatty acid profiles (\% of total fatty acids) and cholesterol content (mg/100g) in whole eggs of different genotype hens

\begin{tabular}{|c|c|c|c|}
\hline & $\begin{array}{c}\text { Hy line - free } \\
\text { range }\end{array}$ & Hy line - Cage & $\begin{array}{c}\text { Naked neck - Free } \\
\text { range }\end{array}$ \\
\hline $\mathrm{C} 14: 0$ & 0.22 & 0.23 & 0.24 \\
\hline C15:0 & 0.04 & 0.03 & 0.03 \\
\hline $\mathrm{C} 16: 0$ & 23.51 & 23.47 & 24.31 \\
\hline $\mathrm{C} 17: 0$ & 0.15 & 0.15 & 0.16 \\
\hline $\mathrm{C} 18: 0$ & 8.42 & 8.86 & 8.19 \\
\hline SFA & 32.34 & 32.74 & 32.93 \\
\hline $\mathrm{C} 16: 1$ & 2.11 & 2.14 & 2.15 \\
\hline C18:1 cis-9 & 44.44 & 43.91 & 47.79 \\
\hline $\mathrm{C} 20: 1$ & 0.18 & 0.2 & 0.23 \\
\hline MUFA & 46.73 & 46.25 & 50.17 \\
\hline $\mathrm{C} 18: 2 \mathrm{n}-6$ & 16.95 & 17.3 & 12.68 \\
\hline $\mathrm{C} 18: 3 \mathrm{n}-3$ & 0.84 & 0.61 & 0.9 \\
\hline $\mathrm{C} 18: 3 \mathrm{n}-6$ & 0.07 & 0.06 & - \\
\hline $\mathrm{C} 20: 2 \mathrm{n}-6$ & 0.14 & 0.22 & 0.17 \\
\hline $\mathrm{C} 20: 3 \mathrm{n}-6$ & 0.3 & 0.44 & 0.47 \\
\hline $\mathrm{C} 22: 5$ n-3 (DPA) & 0.11 & - & 0.13 \\
\hline $\mathrm{C} 22: 6$ n-3 (DHA) & 1.07 & 0.75 & 1.26 \\
\hline PUFA & 19.48 & 19.38 & 15.61 \\
\hline $\mathrm{C} 22: 1+\mathrm{C} 20: 4$ & 1.42 & 1.64 & 1.28 \\
\hline UFA & 66.21 & 65.63 & 65.78 \\
\hline Total n-3 & 2.02 & 1.36 & 2.29 \\
\hline Total n-6 & 17.46 & 18.02 & 13.32 \\
\hline$n-6 / n-3$ & 8.64 & 13.25 & 5.81 \\
\hline PUFA : SFA & 0.6 & 0.59 & 0.47 \\
\hline Cholesterol & 177.18 & 197.26 & 237.57 \\
\hline
\end{tabular}

Significantly lower content of $\mathrm{n}-6$ fatty acids was determined in eggs from Naked Neck hens (13.32\%) in comparison to eggs from Hy-line hens housed on free range (17.46\%) and Hy-line hens kept in cages (18.02\%). Content of n-6 fatty acids in eggs from Naked Neck hens was slightly below $15.0 \%$, which is the value reported by Samman et. al. (2009) in eggs obtained in organic production and eggs produced in conventional way. Content of n-3 fatty acids in eggs from Naked Neck hens was significantly higher than 1.36 and $1.34 \%$, which are the values obtained in eggs from conventional production and organic production, respectively, according to same authors. 
Correlation between the housing system and fatty acid profile of egg yolks from autochthonous breed Styrian (Slovenia) was recorded by Simčić et al. (2011), who established $1.71 \% \mathrm{n}-3$ PUFA in eggs from hens reared in cages and $2.50 \% \mathrm{n}$ 3 PUFA in eggs from hens housed on free range. Finding of $2.50 \%$ n-3 PUFA is slightly higher compared to the content of these fatty acids in eggs obtained from hens housed on free range in present study. Content of n-3 PUFA in egg yolk from autochthonous Slovenian hens housed on free range of $14.93 \%$ was somewhat higher than content of these fatty acids determined in eggs of autochthonous Naked neck hens housed on free range $(13.32 \%)$, but significantly lower compared to $17.46 \%$, which is the value determined for eggs of Hy line hens kept on free range.

Milinsk et al. (2003) studied the fatty acid profile of egg yolks from Lohman hens and established correlation between nutrition and content of unsaturated fatty acids. So, in eggs obtained from hens fed commercial mixtures, they established $16.5 \% \mathrm{n}-6$ PUFA, which is somewhat higher compared to content of these fatty acids recorded in eggs from Hy line hens kept on free range and in cages and significantly higher compared to eggs from naked neck hens on free range. Content of n-3 PUFA of $1.02 \%$ in Lohman hens was a half of the value determined in eggs from Naked Neck hens (2.29\%) and eggs from Hy line hens housed on free range $(2.02 \%)$. Depending on the type of used feed mixture rich in n-3 fatty acids, these authors have established the content of n-3 PUFA in the range from 1.58 to $5.44 \%$, and of n-6 PUFA in the range from 15.5 to $26.9 \%$, where the highest content of n-3 PUFA, i.e. the lowest content of n-6 PUFA, was determined in egg yolk from hens fed diet supplemented with flax flour and flax oil. The reverse ratio was established when diet was supplemented with sunflower meal and sunflower oil.

Significant impact of hens diet on fatty acid profile of eggs is also reported by Wang and Huo (2010), who studied the content of fatty acids in eggs of hens fed different mixtures supplemented with sunflower and flax seed in different combinations. As previous authors, they report the highest increase of the n-3 PUFA content and the lowest content of n-6 PUFA in eggs from hens fed diets with flax seed.

Production of eggs with higher content of these fatty acids and favourable n-3 and n-6 PUFA ratio by introducing different supplements to hen diet with natural sources of n-3 PUFA are reported by Woods and Fearona (2009). These possibilities are limited by adverse effects, especially by flax seed and appearance of fish aroma in eggs.. This aroma probably occurs as a consequence of increase in oxidation of UFA, although some authors state that this aroma originates from lipid and non-lipid substances from the feed for layer hens. The taste/aroma of fish in eggs usually occurs when more than $5 \%$ of flax seed or more than $1.5 \%$ of fish meal is added to the mixture for layer hens. Also, there is the possibility of faster oxidation, due to higher content of n-3 PUFA in eggs, which could be avoided by 
adding of $200 \mathrm{mg} / \mathrm{kg}$ vitamin $\mathrm{E}$ in diet, which has anti oxidative effect (Galobart et al., 2001).

Based on the results obtained for toxic elements content $(\mathrm{Cd}<0.001$ $\mathrm{mg} / \mathrm{kg} ; \mathrm{Pb}<0.05 \mathrm{mg} / \mathrm{kg} ; \mathrm{As}<0.01 \mathrm{mg} / \mathrm{kg} ; \mathrm{Hg}<0.005 \mathrm{mg} / \mathrm{kg}$ ) it can be concluded that all three groups of eggs were in compliance with standards stipulated in the Article 9a, Annex 5, Rulebook on maximum residue limits for plant protective compounds in food and feed for which maximum reside limits are established (Official journal of RS No. 25/2010, Official journal of RS No. 28/11).

\title{
Conclusion
}

Based on the obtained data in the study on the proximate composition, fatty acid profile and cholesterol content of eggs from two hen genotypes, Hy line and Naked Neck hens housed in cages and on free range, it can be concluded that slight advantage in regard to the nutritional quality were demonstrated by eggs from Naked Neck hens.

Considering that the implementation of free systems in poultry rearing with native hen population is becoming more present, future studies and research should be continued in this direction.

\section{Acknowledgment}

This paper is a part of the Project EVB: TR - 31033 financial supported by Ministry of Education and Science of the Republic Serbia.

\section{Uporedna analiza profila masnih kiselina i sadržaja holesterola konzumnih jaja različitog genotipa kokoši}

\author{
Z. Pavlovski, Z. Škrbić, M. Lukić, S. Lilić, V. Krnjaja, N. Stanišić, V. Petričević
}

\section{Rezime}

Alternativni (nekonvencionalni) sistemi držanja živine uvode se u proizvodnju, s jedne strane radi dobrobiti kokoši i, s druge strane zbog kvaliteta jaja, odnosno u cilju uspostavljanja veze između kvaliteta života kokoši i kvaliteta proizvoda.

U radu su prikazani podaci uporedne analize osnovnog hemijskog sastava, profila masnih kiselina i sadržaja holesterola jajima kod genotipa Hy line i gološijana držanih u različitim sistemima držanja - kavezi i ispust. 
Jaja gološijana gajenih u sistemu sa slobodnim ispustom imala su statistički značajno veći sadržaj suve materije, masti, proteina i pepela u odnosu na genotip Hy line držanih u oba sistema. Jaja kokoši genotipa Hy line držanih u sistemu sa slobodnim ispustom u odnosu na kavezni, imala su veći sadržaj suve materije, masti i pepela, mada razlike nisu bile statistički značajne, dok je razlika većeg sadržaja belančevina kod Hy line kokoši držanih u kavezima u odnosu na ispust bila statistički značajna.

Znatno manji sadržaj n-6 masnih kiselina utvrđen je u jajima gološijana $(13,32)$ od onog utvrđenog u jajima kokoši Hy-line držanih na ispustu $(17,46)$ i Hyline držanim u kavezima $(18,02)$.

Sadržaj toksičnih elemenata $(\mathrm{Cd}<0,001 \mathrm{mg} / \mathrm{kg} ; \mathrm{Pb}<0,05 \mathrm{mg} / \mathrm{kg}$; $\mathrm{As}<$ $0,01 \mathrm{mg} / \mathrm{kg} ; \mathrm{Hg}<0,005 \mathrm{mg} / \mathrm{kg}$ ) u sve tri grupe jaja ispunjavaju uslove propisane čl. 9a, priloga 5, Pravilnika o maksimalno dozvoljenim količinama ostataka sredstava za zaštitu bilja u hrani i hrani za životinje i o hrani i hrani za životinje za koju se utvrđuju maksimalno dozvoljene količine ostataka sredstava za zaštitu bilja.

\section{References}

APPLEBAY M.C. (2001): Housing for laying hens in North America and Europe. Biotechnology in Animal Husbandry, 17, 5-6, 33-36.

AOAC (1995): Official methods of analysis. 15th ed. Association of Official Analytical Chemists, Washington, DC, USA.

GALOBART J., BARROETA A.C., BAUCELLS M.D., GUARDINOLA F. (2001): Lipid oxidation in fresh and spray-dried eggs enriched with omega -3 and omega- 6 polyunsaturated fatty acid during storage as affected by dietary vitamin E and canthaxanthin supplementation. Poultry Science, 80, 327-337.

ĐUKIĆ-STOJČIĆ M., PERIĆ L., BJEDOV S., MILOŠEVIĆ N. (2009): The quality of table eggs produced in different housing systems. Biotechnology in Animal Husbandry, 25, 5-6, Book 2, 1103-1108.

MARASCHIELLO C., DIAZ I., REGUEIRO J.A.G. (1996): Determination of cholesterol in fat and muscle of pig by HPLC and capillary gas chromatography with solvent venting injection. J. High Resol. Chromatogr, 19, 165-168.

MILINSK M.S., MURAKAMI A.E., GOMES S.T.M., MATSHUTA M., DE SOUZA N.E. (2003): Fatty acid profile of egg yolk lipids hens fed diet rich in n-3 fatty acid. Food Chemistry, 83, 287-292.

PAVLOVSKI Z., HOPIĆ S., LUKIĆ M. (2001): Housing system for layers and egg quality. Biotechnology in Animal Husbandry, 17, 5-6, 197-201.

PAVLOVSKI Z., LUKIĆ M., ŠKRBIĆ Z. (2002): Uticaj sistema držanja kokoši nosilja na kvalitet i neškodljivost konzumnih jaja. Biotechnology in Animal Husbandry, 18, 5-6, 121-127. 
PAVLOVSKI Z., ŠKRBIĆ Z., LUKIĆ M. (2009): Programs of natural food and alternative systems in production of table eggs. XIII Symposium Feed Technology. Proceedings, 124-136.

PAVLOVSKI Z., ŠKRBIĆ Z., LUKIĆ M. (2010): Table quality of layer eggs from various production systems. XIV International Symposium Feed Technology, Novi Sad, 19-21 October. Proceedings, 222-227.

PERIĆ L., MILOŠEVIĆ N., TOLIMIR N., ŽIKIĆ D. (2007): Results of egg production in different housing systems. Biotechnology in Animal Husbandry, 23, 5-6, Book 1, 496-502.

SAMANN S., KUNG P.K., CARTER L.M., FOSTER M.J., AHMAD Z.I., PHUYAL J.L., PETOCH P. (2009): Fatty acid composition of certified organic, conventional and omega -3 eggs. Food Chemistry, 116, 911-914.

SENČIĆ Đ., ANTUNOVIĆ Z., DOMAĆINOVIĆ M., ŠPERANDA M., STEINER Z. (2006): Kvaliteta kokošijih jaja iz slobodnog i kaveznog sustava držanja. Stočarstvo, 60, 3, 173-179.

SIMČIĆ M., STIBILJ V., HOLCMAN A. (2011): Fatty acid composition of eggs produced by Slovenian autochthonous Styrian hen. Food Chemistry, 125, 873-877. SPIRIĆ A., TRBOVIĆ D., VRANIĆ D., ĐINOVIĆ J., PETRONIJEVIĆ R., MILIJAŠEVIĆ M., JANKOVIĆ S., RADIČEVIĆ T. (2009): Uticaj masnih kiselina u hrani na sastav masnih kiselina i količinu holesterola kod kalifornijske pastrmke (Oncorhynchus mykiss). Tehnologija mesa, 50, 179-188.

SRPS EN ISO 5509:2007 Animal and vegetable fats and oils - preparation of methyl esters of fatty acids.

WANG L., HUO G. (2010): The effect of dietary fatty acid pattern on layer's performance and egg quality. Agricultural Science in China, 9, 2, 280-285.

Received 30 June 2011; accepted for publication 15 August 2011 